\title{
Where the Truth Lies in Translated Poetry: a Doris Kareva Poem in English
}

\author{
MIRIAM McILFATRICK
}

\begin{abstract}
The article explores what the examination of original and translated poems side by side reveals about the nature of poetic communication. A Doris Kareva poem is analysed to determine how (rather than what) it means, identifying bonds of meaning created by sound and ambiguity as much as by syntactic or lexical relations. Two translations are analysed which suggest that a poem cannot be captured in the transferral of a graspable message or isolated lexicalised concepts, nor through the skilful handling of poetic devices. A third translation is proposed that aims to replicate the lexical, semantic and phonetic strands that constitute the coherence of the original while also generating ambiguity as a bound and binding feature of the new poem. Finally, the poem is posited as the presence of meaning, manifest in the effects it produces that make us attend to it as a poem.
\end{abstract}

Keywords: translation, poetic effects, ambiguity

DOI: http://dx.doi.org/10.12697/IL.2013.18.1.12

All poets lie. Yet it is our function to try to tell the truth. The attempt to do this is what I call "a poem". As I once said in a poem "a writer is essentially a crook. With used furniture he makes a tree." What I have tried to do is to make the non-verbal verbal; $[. .$.

Anne Sexton, 2003

Understanding what happens when translation takes place has become a central concern in many fields. Translation is nowadays viewed as a vital link in cultural exchange, translators as actors in the field of cultural production, and translated texts as providing empirical data for the study of cultural interaction. Comparative literature has an obvious - though somewhat ambivalent - 
relationship with translation. In asking fundamental questions about the nature of literature, comparatists work across cultural and linguistic boundaries and rely on multilingualism and translated texts. Translation is inevitable and illuminating, but questions of overdependence on translated texts and inadequacy of both quality and selection follow in its wake. There are regularly attempts by comparatists to bring to wider attention the work of writers whom they consider unjustly ignored on account of their belonging to a "small" nation or language or, particularly in the case of poetry, the lack or impossibility of adequate translation - often on the grounds of the supposedly unsolvable dilemma of retaining both form and content. Such reasoning hints at a view of language as a barrier and translation as an obstacle. This is in stark contrast to the view expressed by George Steiner in his inaugural address, delivered on his appointment as Weidenfeld Professor of European Comparative Literature at the University of Oxford in 1994, where he identifies translation as something akin to a supporting pillar of comparative literature - for better and for worse: "Jubilant at the intractable diversity of Babel [...] comparative literature is an art of understanding centred in the eventuality and defeats of translation" (Steiner 1995: 10 - my emphasis). This has prompted me to question how the study of poems in translation enhances our understanding and appreciation of poetry. This is not a question of assessing or passing judgment on the selection or quality of translated poems. Instead my focus is the examination of original and translated poems side by side for what they reveal about the qualities of the original in particular and the nature of poetry in general.

It is widely accepted that any given poem will spawn multiple versions in translation; furthermore, when translated back by other translators, these translations will not produce the same or the original poem. Such divergence and asymmetry convinces many that more and different translations are always needed in order to show more of the facets that together make up the original. What is often lacking alongside this acceptance of moreness and otherness is an attempt at a unifying account of what the original is and how it coheres. In this article I will analyse three translations of a poem by the Estonian poet Doris Kareva with a view to identifying what they reveal about the nature of poetic communication and how they inform our understanding of what poetry is.

\section{The poet behind the poems: Doris Kareva}

A distinguishing feature of Kareva's poetry is her exploration and expression of the enduring themes of human reflection: life, death, time, eternity, truth, beauty, love, loss, existence, absence, being and nothingness - they all find a 
McILFATRICK

place in her work. Her poems touch on metaphysical and existential matters that define how the individual encounters and relates to the surrounding world. Themes that inevitably attract abstract language are rendered textural, visible, tangible, e.g. precarious love as living at the foot of a volcano, or poetry in a grain of sand. Likewise, even the most abstract subjects take on sensuous or physical qualities, e.g. truth throbs, sorrow rusts desire, loss and fear cling to flesh like pain. So although she writes that "the depths of thoughts are somehow riddle- / like" and that "to render a human life visible / and give it to many truly / is impossible"2, she still attempts to plumb those depths and reveal that life as she gives voice to the physical world around her.

One reason for the depth and clarity of Kareva's poetry lies in her ability to create ambiguity and suggest harmony at the same time. At times, her words hint at or flit around a meaning or an idea, illuminating in a manner that has been described as "oracle-like" (Kaus 2003). She sets up dualities, divisions and oppositions and counters them with returns, cycles and echoes. Harmony is achieved through a kind of balancing act: the balancing of the universal with the particular, the ideal with the sensuous. And, it is due in equal measure to her honing of language. Many poems are minimalist (some only 3 or 4 lines, half a dozen word on a page), constituting a blend of spareness and precision of expression. Whatever their length, they aspire to grasp and communicate something essential in a way that is both defining and definitive. Sounds and meanings overlap and interact to the extent that whole poems appear diamondlike: resilient, incisive and multi-faceted all at once. The overall impact is often that there is no more to be said on the matter.

Kareva also weaves ambiguity into and around language itself. She often refers to language explicitly in her poems, articulating it as both demanding and denying expression, as both facilitating and forbidding revelation. She speaks of it variously as a source, a power, a material: "Yes. In the beginning was the Word."; "A spring in the stony desert / the omnipotent Word"; "As solid as rock, / as light as down / is the Word - as limpid / and pure as gold"3. But, it is also a force to be reckoned with, and she equally often writes of the very difficulty of writing: the "unheeding" words that she attempts to "shepherd", the

1 Mõtete põhi on mõneti mõistatus- / lik (Kareva 1997: 57). [Translations of quotations from Estonian are mine. M.M.]

2 Üht inimelu teha nähtavaks / ja anda paljudele päriseks / ei saa (Kareva 1991: 122).

3 Jah. Alguses oli Sõna. (Kareva 1991: 7); Allikas kivikõrbes / kõigeväeline Sõna (Kareva 1997: 93); Nii kindel kui kivi, / nii kerge kui sulg / on Sõna - nii selge / ja puhas kui kuld, (Kareva 2002: 99). 
"forbidding" language that is her medium ${ }^{4}$. The poet is aware of herself as tied to her calling and to her medium of expression, and declares it time and again in no uncertain terms: "If I don't talk about this / I'll die. / If I admit to it / it'll kill me." The recognition that language forbids her to do the very thing she must do leads her to coin the phrase "keelav keel" - "forbidding language" (Kareva 2007: 27). Perhaps the clearest expression of what drives Doris Kareva appears in an article she has written about her father, the composer Hillar Kareva, where she says of both human existence and the act of creation: "our means are limited, our possibilities limitless" (ib. 5). The article is entitled "Lesson in Harmony" and therein lies the key to Kareva's poetics - the practice of achieving some kind of concord between that which seeks expression through language and language which does not allow it to be expressed.

The poem selected for analysis is from Kareva's 2002 collection Mandrago$r a$, a collection marked by minimalism and the interplay of sounds and echoing rhymes - a kind of "phonic algebra" ("häälikuline algebra") that dispels the notion of linguistic indeterminacy (Krull 2003). Words and syllables appear to be guided by some kind of force, a "secret formula" that goes beyond conscious linguistic choice. It is as if the poet does not so much express thought or vision but thinks the poem into existence. This is reminiscent of Barthes's notion of text as "tissue": a generative idea of text coming into being through a perpetual interlacing of thought process and language, at the same time as the subject is coming undone into the tissue (Barthes 1973: 126-127). Mandragora oscillates between two poles: at times, a truth seems to be half-hidden/ half-revealed in and by the words; at other times, the whole momentum of a poem seems to depend solely on the physicality of the words. The collection opens with a section entitled "Forbidden Book" ("Keelatud raamat") - already ambiguous, for truly forbidden books do not bear labels that declare them to be so. A reader who is familiar with Kareva's work will probably also be put in mind of her preoccupation with language, for she has placed language ("keel" in Estonian) at the fore, tucked neatly and ambiguously into "keelatud" ("forbidden") - attracting attention but apparently denying or defying entry. Is this a coy invitation? Is it a hint that language lies at the heart of what is forbidden,

4 Kui kirjutan, / karjatan sõnakuulmatuid sõnu / [...] kirjutan üleni keeldumuskeeles - When I write, / I shepherd unheeding words / [...] I write in an utterly forbidding language (Kareva 2002: 10).

5 Kui ma ei kõnele sellest, / ma suren. / Kui tunnistan seda, / see tapab mu. (Kareva 2002: 7).

6 Meie vahendid on piiratud, meie võimalused piiritud.

7 varjatud valem (Kareva 2002: 27). 
McILFATRICK

that language is the root of the problem? These may well be the questions that beckon the translator and issue a warning at the same time.

\section{Original poem : new poems}

Most comparative analysis of translations focuses on divergence between translation and original and differences between translations of the same text (e.g. Parks 2007). The assumption is that both point to those places in a text where translation is particularly challenging, e.g. where the original is semantically dense or deviant ${ }^{8}$ or enigmatic. This approach, while illuminating, should not deter us from exploring another potentially fruitful source of empirical data the similarities between translations. Since translation aims at achieving some kind of equivalence, it is also relevant to look at those places where translators have made the same linguistic choices to see what they reveal. Can we assume that identical word choice on the part of two or more translators reflects a reliance on primary literal meanings or a limited intention in the original? Particularly in poetry, where each word carries a high proportion of the significancebearing load of the whole, no word should be left unquestioned simply because it seems to represent an obvious choice - poetry does not state the obvious.

The poem selected for analysis - "Läbi pimeduse kipub käpp" - appears below, alongside an approximate literal version (including range of meaning for individual words). It will be analysed along with three translations: two (T1 and T2) were provided in manuscript form by Doris Kareva, and since neither translation has been published, the names of the translators are not given. The third translation (T3) is my own.

\section{Läbi pimeduse kipub käpp küünitama valguvat. \\ Ei tea \\ iial, mis jääb igatsuse külge.}

Noored toored sõnad, teravad ja tõesed, tõlkimatud, laua peal juba laeni.
Through the darkness strainsstrives-longs-tends a paw to reach-grasp the flowing. (One) does not know ever what will stick to longing.

Young raw words, sharp and true, untranslatable, on the table up to the ceiling.

8 Here "deviation" is understood as language going beyond common (and constantly changing) linguistic usage, thereby drawing attention to itself as language while remaining in harmony with and contributing to the coherence of the text as a whole. 
Where the Truth Lies in Translated Poetry: a Doris Kareva Poem in English

Lama, sõnatu, neela pimeduse verist sülge.
Lie, wordless, swallow darkness's bloody spit.

\section{"Läbi pimeduse kipub käpp"}

Appearing as it does in the "Forbidden Book" section of Mandragora, it comes as no surprise that this poem engages with language, specifically words ("sõnad"). It opens with a distinctly animal-like or instinctual response to a moving entity ("valguvat") that is as yet unknown or unknowable - a stealthy reaching out (a paw in the darkness) to touch it, to see what it is. The poem ends with a sense of surrender or resignation, almost as if crawling away to lick one's wounds. It is only in the second stanza that an identifiable subject appears: "words" which are variously "young, raw, sharp, true and untranslatable", alluding both to their still developing nature ("young", "raw") and to their already defined and defining qualities ("sharp", "true"), including their potential to deny (re)expression ("untranslatable"). Only "untranslatable", by hinting at one who might translate them, implies a presence that is dependent on them, perceptible as the second person singular addressee of the imperatives "lie" and "swallow", and left "wordless" ("sõnatu"10) at the end. The poem is highly suggestive of the dilemma of the poet and the paradox of the creative process. The dilemma arises from the poet's desire and struggle to make known some partially, because dimly, perceived truth that neither she nor the language at her disposal can as yet fully grasp - in the sense of understand or articulate; what Falck verbalises as "a 'reaching-beyond' into an incompletelyarticulated extra-linguistic presence” (Falck 1995: 22). The paradox is that the poet only exists once the poem issues from her lips or appears in print in front of her, yet the poem requires there to be a poet in order to make it. Once the poem exists, it dispossesses the poet - affirmative of itself and apparently sufficient unto itself.

This poem hinges on stanza two. Orthographically, the stanza poses as a single sentence with its initial capital letter and final full stop; at the same time, it illustrates the relative freedom from the constraints of grammar and syntax that is characteristic of poetry, consisting as it does of five adjectives ("noored", "toored”, "teravad”, “tõesed”, "tõlkimatud”), three nouns ("sõnad”, "laua”,

9 valguvat - a slow running, flowing, pouring or spreading movement, e.g. of liquid or very fine grain

10 sõnatu = sõna 'word' + the ending -tu (denoting '-less' or 'without') 
McILFATRICK

"laeni"), one conjunction ("ja”), one adverb ("juba”) and one postposition ("peal”), but no finite verb. This lack of a finite verb does not generate looseness or a sense of incompleteness, for the rolling assonance and alliteration of the adjectives binds them together: "noored toored sõnad, teravad / ja tõesed, tõlkimatud". They are not isolated or free-standing adjectives, individually "describing" a single characteristic of "words". Instead, they share a common identity and power as the very words that define "words". It is as if they are simultaneously in orbit around them and creating an impenetrable shell around them. They do not describe, they act. Groupings become marked that direct attention to overlapping or combined nuances (on the one hand, "young and raw" hold promise and potential to mature, to be shaped; on the other, "sharp, true and untranslatable" encompass already formed and well-defined abilities - to penetrate, to remain constant, to resist). Where syntax is loose, sound has created bonds of meaning - as the oral poetician Zumthor suggests, words have come to "inhabit voice" (Zumthor 1983: 7). Indeed, this stanza seems to illustrate Zumthor's conceptualisation of poetry as something which calls into being and is less concerned with meaning than with linguistic beingness, with the result that language is immediate and produces "significations" that are intimately linked to the forms they take on (ib. 99).

Throughout the poem and regardless of whether syntax is loose or tight, acoustic effects can be perceived as working together towards the internal tension and coherence of the poem. In the first stanza, which is syntactically and grammatically standard usage in Estonian, a dual alliteration centred on the straining paw ("kipub käpp") is noticeable. It is a double effort: (i) to penetrate the darkness - "Läbi pimeduse kipub käpp" and (ii) to reach or grasp something - "kipub käpp / küünitama”. This overlapping dual alliteration draws attention to both as part and parcel of the same effort - drawing attention in the sense that it makes us "attend" to the text as a poem, i.e. for its revelatory quality (Falck 1995: 87). Similarly, rhythm reveals itself as meaning that is untranslatable into language, for example, "laua peal / juba laeni" at the end of the second stanza. Certainly, it is easy to visualise drafts piling up on a table, but the intent of this neat turn is to capture the enormity and the immediacy of the dilemma of dealing with words. The dimensions are indicated by the horizontal ("on the table") and the vertical ("up to the ceiling") and the sheer amount of words is emphasised by the fact that they stretch from being "on" ("peal") the table "right up to" ("juba ---ni ${ }^{11}$ ") the ceiling; they are an encroaching physical presence. All this is revealed in an abruptness that seems to want to speak no more of the matter, even suggestive of a desire to be done with it.

11 laeni = lae (genitive of lagi 'ceiling') + the suffix -ni (denoting 'up to'). 
As for the ambiguities and uncertainties that are assumed to be part of the process of reading poetry, this poem is no exception. In the first stanza, "Ei tea / iial" foregrounds the state of not knowing with its lack of a subject pronoun (it is a standard expression, commonly used in the sense of "you never know"). Here it casts the net of who might not know wide. Possible candidates are: the animal-like presence evoked by "paw" (1.1), the implied presence facing the "untranslatable" words (1.6), and the "wordless" presence in the last stanza for "sõnatu" can be both adjective and noun (one who is wordless). They may be one and the same. In the end, it feels as if only the poem knows and has the final word.

\section{"Through the dark a claw strives" and "Through the darkness strives a paw"}

\section{T1}

Through the dark a claw strives to grip the pouring flow.

There's no knowing what will cling to longing.

Young raw words, sharp and true, untranslatable, on the table

up to the ceiling.

Lie there, wordless, swallow the bloody spittle of the dark.
T2

Through the darkness strives a paw clawing at the flow. One never knows what will adhere to desire.

Young raw words, sharp and true, untranslatable, on the table reaching the ceiling.

Lie down, wordless, swallow the bloody spittle of darkness.

The first lines of these two translations already point to a similarity between them that is sustained throughout; for this reason, I will analyse them together. A word count is relevant in any analysis of Kareva's poetry given that it tends towards minimalism yet opens up complex issues for contemplation. T1 and T2 contain 44 and 40 words respectively; most noticeable, however, is the fact that a total of 28 words are identical and in the same lines, if not always the same position. In other words, approximately two thirds of the words that the translators have arrived at independently are the same. Below is a graphic 
McILFATRICK

representation of the distribution of the words that are identical in the two translations ${ }^{12}$ :

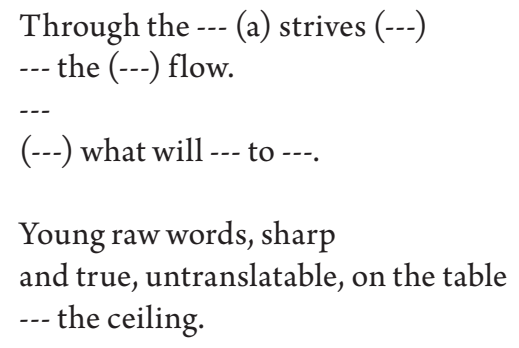

Lie --- , wordless, swallow the bloody spittle of --- .

What is immediately obvious is the degree of similarity in the second stanza, which deals precisely with the nature of words. Both translations contain the same five adjectives (young, raw, sharp, true, untranslatable), each of which fulfils a standard adjectival role of communicating a particular attribute of the noun it qualifies ("words"). Viewed together the adjectives appear to list discrete individual characteristics; however, four of them (young, raw, sharp, true) have multiple meanings and collocations, any of which could reveal "words" in a new light. For example, "young" may allude to the early stages of growth or development, newness, freshness, etc.; "raw" to unprocessed, crude, inexperienced, painfully exposed, etc.; "sharp" to having a cutting edge, clearly defined, penetrating, biting, etc.; and "true" to factual, real, loyal, exact, pertaining to truth, etc. At times, the adjectives seem to relate to each other as much as to "words" (e.g. the juxtaposed "young" and "raw" tend to coincide in inexperience and immaturity); at other times, they move apart and in different directions (e.g. "sharp" as biting or cutting collides with "true" as loyal). As they drift around and apart, meaning is diverted and deferred. In a sense, they become emblematic of the multiplicity of meaning generated by words and the impossibility of tying them exclusively to intended or interpreted meanings. Only "untranslatable" seems fixed, not least on account of its prefix "un", which denies it the positive charge of the other four but allows it to express its negative ability. As such, it acts as a kind of linchpin holding the other four adjectives

12 --- indicates a difference in word choice; brackets (---) indicate a difference in word position. 
to that same essential quality that is its own defining quality. In this way, "untranslatable" competes with "words" as a centralising force in the stanza.

In the same stanza, the alliteration of "true/untranslatable/table" is noticeable; it allows "true" and "untranslatable" to collaborate, audibly seeking to remove "true" from the group of potentially drifting adjectives - in spite of the "and" which seeks to align it with "sharp". It also introduces "table" as a distracting and detracting third element that is hard to place in the equation of the line. Hence line 6 seems to tend towards sound effect purely for the sake of it rather than contributing to an emerging discourse of the poem. Furthermore, it leaves "up to the ceiling" (T1) and "reaching the ceiling" (T2) dangling in line 7 , for both become ungrammatical to no obvious purpose; in terms of the stanza they are at a loose end.

In the last stanza, there is again little to distinguish between the word choice and syntax of the two poems. Both offer "wordless / swallow the bloody spittle ...", the sound effect marking the contrast between what is not in the mouth (words) and what is ("spittle of the dark/darkness"). Uncertainty appears with "bloody", however. In the context of a spoken imperative, "bloody" tends to resonate as a slang expletive intensifier, communicating an emotional response (frustration or irritation perhaps). As such, it would be excluded from qualifying or defining "spittle of the dark/darkness" and from relating to "sharp" (and potentially cutting) words in the previous stanza. It represents an ambiguity that barely interacts within the poem.

The first stanza is where we see the greatest difference between the two translations. In T1, "Through the dark a claw strives / to grip the pouring flow" must depend on image for impact, given the fairly standard syntax and the absence of any meaning-bearing rhythmic or acoustic effect. But a claw in the dark is an arresting image. However, what it provides by way of palpability becomes progressively puzzling. The initial effort needed to form a mental picture of how a single claw might "grip" something as apparently liquid and ungraspable as is suggested by "pouring flow" is compounded (and potentially confounded) by the challenge to conceive of the latter, for the heaviness of "pouring" contradicts the more measured movement and ease of "flow". In T2, an animal-like presence and behaviour are clear and even reinforced by the marked assonance in "Through the darkness strives a paw / clawing at the flow". However, the reversal of standard subject-verb order in "strives a paw" focuses attention on the verb (as the deviating word) more than the paw; in so doing it detracts from the enjambment, which is not in any case very pronounced. Then, in the very next line, the animal presence gives way to an impersonal "One never knows", which introduces uncertainty as to who does not know - the same animal presence, an observing poetic persona, or anyone in general? - for the impersonal 
McILFATRICK

pronoun carries embedded within it the notion of a personal pronoun. T2, in contrast, focuses on uncertainty itself, on the not-knowing that is a stated presence indicated by “There's no / knowing”. Spread over two lines, it allows for the deferral of what is not (known), and the run-on sound effect (flow/no/ knowing) is every bit as fluid as the "flow" that precedes it and feeds it. It is an enjambment that resonates as more than a poetic device.

Although different, the lexical choice and pairing in "cling to longing" (T1) and "adhere to desire" (T2) have an audible meaning-reinforcing effect and both sustain the rhythm of lines 3 and 4 of their respective poems. In stanza 3, however, "Lie there, wordless" (T1) and "Lie down, wordless" (T2) are not equally effective within the discourse of the poem. Certainly, "lie" on its own would generate a whole new semantic thread in the poem on account of its ability to refer to the uttering of an untruth as well as to physically adopting a prostrate position. The ambiguity would find much to feed off and into in the poem, so a second element is needed if this is not the intention of the translator and if it is not to become the intent of the poem ${ }^{13}$. Furthermore, a second beat after "lie" sustains the rhythm of the line. Hence, T1's "lie there, wordless" achieves a rhythmic effect that is carried over into "swallow" in the next line, effectively issuing two abrupt imperatives. However, T2's version, "lie down", with its two stressed beats, jars with the stressed-unstressed beat of "wordless". The other distracting aspect of "lie down" is its primary connotation of lying down to rest. There has been nothing in the discourse of the poem to suggest repose at the end.

\section{"A paw extends in the dark"}

T3

A paw extends in the dark

to probe the flow.

There's no

knowing what will cling to longing.

Raw, rough-edged words, terse

and true, translation-proof, from table

to rafters.

Lie there, wordless, swallow the blood-spit of the dark.

13 Here I distinguish between "intention" as a decision to take a particular action and "intent" as a firmer will or resolve to achieve something. 
The third translation (T3) has less in common with either T1 or T2, hence it is treated separately here.

The first stanza opens with the image of a paw stretching out purposefully towards a vaguely referenced moving entity ("flow"). The phrase "in the dark" embraces both being in darkness and being in a state of unawareness or ignorance. Furthermore, its position at the end of the line and its function as an adverbial that qualifies "extends" mean that the paw must go through this same dark in order to reach its objective - "to probe the flow" - as revealed in the next line. "Probe" embraces the notions of touching or questioning closely in order to examine and understand something that is an unknown quantity. This renders "flow" as both an obscure focal point and a moving target. This draw of the unknown or the unknowable resonates throughout the entire first stanza: the alliteration and assonance in "paw / probe / flow" carries over into "there's no knowing" (11.3-4), which in turn echoes "in the dark" (1.2).

The second stanza sees a shift in focus and syntax: five adjectives, three nouns, two prepositions, and one conjunction jostle for attention in the absence of a finite verb that would express or imply a subject. The adjectives that surround "words" express individual characteristics and at the same time collaborate in developing two binding semantic threads, each in its turn composed of two or more strands. First, the shared alliteration in the juxtaposed adjectives "raw, rough-edged words" gives voice to a shared quality - a lack of refinement. And, each adjective specifies its contribution to this lack: "raw" - its natural and unprocessed quality; "rough-edged" - its incompletely processed or unpolished state, with "-edged" adding a potentially awkward and even hurting dimension. Thus the lack reveals both depth and complexity. Similarly, the shared alliteration of "terse / and true, translation-proof" calls attention to an overarching sense of detached completeness that comprises three strands: the neat pithiness of "terse", the sufficiency unto itself of "true", and the imperviousness of "translation-proof". The hyphened-on "-proof" foregrounds the ability to withstand and tacks on the notion of proof - evidence establishing the truth of something. Does this allow "translation-proof" to speak of translation's ability to simultaneously conceal and reveal truth (the very focus of this article)? The alliteration in "translation-proof, from table / to rafters." does support the idea of piles of translation drafts as evidence of the resistance of words. Thus the two compound adjectives in creating a space in which to express themselves also open up a space which other meanings may occupy - further proof of their translation-proofness.

The stanza rounds off with "from table / to rafters"; its economy of expression is threefold: the omission of the definite articles that standard usage expects, an allusion to the phrase "packed to the rafters" (meaning full 
McILFATRICK

to overflowing) which expresses the enormity of the problem, and a marked acoustic effect. The whole intent of this four-word phrase is to locate the words about "words" in the here and now but without adopting their self-centred and self-stating stance - it is as much presence as verbal statement. In the final stan$\mathrm{za}$, another linguistic deviation owes its existence to the overwhelming impact of words in the discourse of the poem. The image in the last line contains a suggestion of bleeding tongue or lips - bitten or hurt on rough-edged words? The one who is addressed accepts her situation without a word ("wordless"). In this context and word-company, "swallow" conjures up the notion of swallowing one's words - usually in humiliation. All that is left to swallow is the hurt ("blood-"), to swallow what is usually spat out. And so "blood-spit", which is not standard usage, can come into being in the context of the poem and generate meaning as part of the discourse of the poem. Thus the poem ends with meaning generated out of the dark, precisely what obscured it at the beginning.

\section{What difference do translations make?}

Having looked at what the original and the translations do in and on their own terms, let us now consider what they reveal in comparison.

First of all, in comparison to the original, T1 and T2 reveal a great deal of what Steiner (1998: 67) refers to as "similar saying" which detracts from the transferral of the bonds of meaning and the rhythm of the original. Certainly, translators inevitably weigh up primary literal meanings of words while translating (for translation is a process before it leaves a product); it is a useful first step, primarily showing how the languages (original and translating) function differently and how and where the potential of the language of the original is exploited to poetic effect. But when we read or hear a poem for pleasure, we do not pass through some kind of "literal meaning stage" (Pilkington 2000: 90) which we later modify or reject on gaining a sense of what the poem is "getting at". In T1 and T2, however, the same saying remains in the end product, manifest in three tendencies, all of which effectively and essentially set the new poems at a remove from the original. First, a reliance on primary meanings of individual words or phrases leads to the loss or distortion of the bonds of meaning of the original (11. 1-2, 5-7, 9). Such bonds are identifiable in, for example, the lexical sets, semantic strands and acoustic effects that together construe a discourse that cannot be matched by literal translation of isolated words bound only syntactically. Second, the use of non-standard grammatical forms or syntax as a result of emulating a particular word order or word position in the original. This generates instances of noticeably deviant linguistic use but without 
contributing to the coherence of the poem as a whole (1. 1 (T2); 11. 6-7) Third, the translating away of the enigmatic and the elusive: e.g. "valguvat" as "pouring flow" (T1); also "kipub", which has many different renderings in English, all dependent on context, and is therefore a rather slippery word; in T1 and T2 it is hardened into "strives". It could fruitfully be combined into a prepositional or participial alternative that would focus on effort directed at a goal - which is, after all, the thrust of this particular poem.

In contrast, $\mathrm{T} 3$ takes its cue from the original in generating lexical, semantic and phonetic strands that together constitute its coherence, rhythm and voice. In relation to the original, some elements may not do enough (e.g. is "flow" as deliberate and ponderous as "valguvat"?) and some may go beyond the poet's intention or the intent of the original poem (e.g. does "translation-proof" allow the notion of truth to intrude and alter the discourse? do the hyphenated words overshadow the others and create an imbalance?). What is sure, however, is that they are all part of and participate in the new poem - nothing is redundant.

And this leads to the other main point revealed in a comparison of all four poems. While $\mathrm{T} 1$ and $\mathrm{T} 2$ are not by any means lacking in poetic devices (alliteration, assonance, metrical variation, lineation are all employed), they are not always those of the original poem nor do they all achieve poetic effects. For example, in the second stanza, the alliteration in line 6 changes both the focus and the rhythm of the original (conversely, the lack of any marking or binding device in line 5 produces a looseness of meaning not present in the original). In T3, alliteration, assonance, metre, and lineation are exploited poetically, i.e. to mark or make manifest linkages that go beyond the words on the page. For example, "A paw extends in the dark / to probe the flow" works on the ear and on the mind's eye; it tells what it manages to show, by gesturing at - rather than naming or describing - a truth or a presence that is intuitively sensed.

\section{Where the truth lies}

Translated poems are revealing. The analysis of the two primarily literal translations here suggests that a poem cannot be captured in the transferral of a graspable message or isolated lexicalised concepts, nor through the skilful handling of poetic devices, for the poem is not encoded in the words on the page or hidden in verbal sounds. The poem is not "about" something, it is the thing itself in the sense that it is an immediate presence of meaning - manifest in the effects it produces that make the reader attend to it as a poem. As such, it has an "ability to reveal something significant about how language, or therefore reality itself, coheres or is organized" (Falck 1995: 113). 
McILFATRICK

Much is made of the ambiguous nature of poetry, though this is rarely defined; instead, it is commonly referred to as a poem (or part of a poem) offering a number of alternative meanings from which to choose. On the basis of this analysis, I would suggest that poetic ambiguity (i.e. that is worth attending to) is a bound and binding feature of the poem. It interacts within the poem by engaging the reader in holding in abeyance an array of meanings as she proceeds, meanings that are generated by and feed into the emerging discourse of the poem. As such, it is effort that rewards, for it actively enriches the experience of the poem, making thoughts and feelings both more complex and more precise. Kareva's "ei tea / iial" and corresponding "there's no knowing” are fitting testament to this.

We may say, then, that a poem does not intend to be obscure, though it "probes" obscurities in its linguistic and ontological going-beyond. There has long been a tendency to regard original poems as enshrining some kind of "untranslatable" truth, and this has discouraged many translators from exploring the potential of their own language in order to produce a translation that is also a new poem. Hence the value of comparing translated poems in order to see how they rebound on the original. A comparison focussed on similarities is revealing insofar as similarities offer a ground where we may discover paths and patterns of understanding. Whether words are viewed as "untranslatable" or "translation-proof" or something else entirely, translated poems are telling. Doris Kareva's probing poem and its translations offer proof of this and of Steiner's belief in the centrality of translation to the art of understanding that is comparative literature.

\author{
Miriam McIlfatrick-Ksenofontov \\ miriammcilfatrick@yahoo.com \\ Tallinna Ülikool \\ Germaani-Romaani Keelte ja Kultuuride Instituut \\ Narva mnt 29 \\ 10120 Tallinn \\ EESTI
}


Where the Truth Lies in Translated Poetry: a Doris Kareva Poem in English

\section{References}

Barthes, R. 2000. Le Plaisir du Texte [1973]. Paris: Éditions du Seuil.

Brown, C., D. Paterson, eds. 2003. Don't ask me what I mean: Poets in their own words. London: Picador.

Falck, C. 1995. Myth, Truth and Literature:Towards a True Post-modernism. Cambridge University Press ( $2^{\text {nd }}$ edition).

Kareva, D. 1991. Armuaeg. Tallinn: Eesti Raamat.

Kareva, D. 1997. Hingring. Tallinn: Huma.

Kareva, D. 2002. Mandragora. Tallinn: Huma.

Kareva, D. 2007. Tähendused. Tallinn: verb.

Kaus, J. 2003. Doris Kareva: Biography. Estonian Literature Information Centre. http://www.estlit.ee/elis/?cmd=writer\&id=15265

Krull, H. 2003. Sõnatalisman. - Sirp, 14.03.

Parks, T. 2007. Translating Style: A Literary Approach to Translation, A Translation Approach to Literature. Manchester, UK: St. Jerome Publishing.

Pilkington, A. 2000. Poetic Effects: A Relevance Theory Perspective. Amsterdam \& Philadelphia: John Benjamins Publishing.

Steiner, G. 1995. What is Comparative Literature? An Inaugural Lecture Delivered before the University of Oxford on 11 October 1994. Oxford: Clarendon Press.

Steiner, G. 1998. After Babel. Oxford: OUP.

Zumthor, P. 1990. Oral Poetry: An Introduction. [Introduction à la poésie orale. 1983.] Minneapolis: University of Minnesota Press. 